\title{
GAMBANG KROMONG SEBAGAI IDENTITAS ORANG CINA BENTENG
}

\author{
Risma Sugihartati \\ Program Studi Bahasa Inggris, Fakultas Bahasa dan Seni \\ Universitas Indraprasta PGRI, Jakarta \\ risma.sugihartati@gmail.com
}

\begin{abstract}
Abstrak
Pemberlakuan Instruksi Presiden No 14 Tahun 1967 memiliki pengaruh berbeda terhadap dua kesenian Cina yakni gambang kromong dan barongsai yang digunakan sebagai penunjuk identitas etnis Cina. Pada kesenian gambang kromong Inpres tersebut tidak dapat diberlakukan karena terkait dengan atribut yang melekat pada gambang kromong itu sendiri. Atribut ini adalah bahwa gambang kromong sebagai kesenian akulturasi dan bukan kesenian yang berasal dari negeri leluhur orang Cina yakni Tiongkok. Pada akhirnya, gambang kromong yang dimiliki oleh orang Cina Benteng menjadi penunjuk identitas ethnic group yang akan memperkuat eksistensi mereka di Indonesia. Tulisan ini menggunakan pendekatan kualitatif dalam bentuk studi kasus yaitu kelompok gambang kromong Sinar Gemilang.
\end{abstract}

Kata Kunci: Identitas, Cina Benteng, Gambang Kromong, Akulturasi, ethnic group.

\begin{abstract}
The enforcement of Instruksi Presiden No 14 of 1967 had a different influence on the two chinese tradition, there are gambang kromong and barongsai. They were used as identity of chinese group in Indonesia. This Inpres cannot be applied on gambang kromong because of the attributes that attached on gambang kromong itself. This attribute as the consequences of cultural acculturation and also its not originates from ancestral land of Chinese. In the end, gambang kromong as part of Cina Benteng tradition become an ethnic group identity and would strengthen their existence in Indonesia. This paper used qualitative approach in the form of case study of gambang kromong group namely Sinar Gemilang.
\end{abstract}

Keywords: Identity, Cina Benteng, Gambang Kromong, acculturation, ethnic group.

\section{PENDAHULUAN}

Penerapan Instruksi Presiden No. 14 tahun 1967 pada masa Orde Baru, berimplikasi besar terhadap kehidupan orang Tionghoa khususnya orang Cina Benteng. Kebijakan yang berlaku mulai 6 Desember 1967 ini menyatakan bahwa setiap ungkapan kebudayaan yang berasal dari kebudayaan Cina harus dilakukan di lingkungan rumah, dan kegiatan yang berkaitan dengan kuil Cina, harus dibatasi di lingkungan kuil. Pada saat penerapan Inpres ini, orang Cina tidak diijinkan untuk menyelenggarakan hari raya Imlek, Cap Go Meh, dan ungkapan tradisi ritual mereka di muka publik. Kesenian Cina seperti barongsai, liong, wayang potehi dan tradisi Cina lainnya menjasi terbatas penampilannya di Indonesia, sehingga semakin lama orang Cina semakin kehilangan identitasnya di Indonesia.

Implikasi lain dari diterapkannya Inpres ini adalah larangan menjalankan tradisi yang diselenggarakan pada hari raya Cina misalnya Imlek, Cap Go Meh, Ceng Beng, Phe Cun, Cioko dan upacara bulan purnama (tanggal 15 bulan kedelapan). Perayaan ini dilarang, pun kesenian yang berperan besar dalam terlaksananya tradisi tersebut. 
Larangan dalam Inpres tersebut mencakup juga larangan membangun kelenteng baru, merenovasi ataupun mengembangkan kelenteng, juga larangan menghidupkan budaya (seni) di antaranya Liong.

Kesenian Cina yang dikenal di masyarakat dalam kaitannya dengan perayaan hari besar Cina adalah Barongsai. Kesenian lainnya yang merupakan akulturasi budaya CinaBetawi adalah musik gambang kromong. Dalam pemberlakukan Inpres No 14 tahun 1967 di bidang kebudayaan dan adat istiadat, kedua kesenian ini mengalami dampak yang berbeda.

Kesenian barongsai misalnya memasuki ambang kematiannya pada sekitar tahun 1950-an ketika pemerintah Indonesia melarang kesenian ini dengan alasan nasionalisme (Danandjaja, 1987). Larangan ini meningkat sekitar tahun 1970-an ketika hubungan antara pemerintah Indonesia dan Cina semakin buruk (Danandjaja, 2002). Kematian Barongsai jelas bukan alamiah, tetapi merupakan fungsi dari situasi politik. Dalam hal ini, Shore dan Wright (1997:3-39) mengatakan bahwa kebijakan memiliki pengaruh yang kuat terhadap kehidupan individu atau masyarakat. Hal ini mempengaruhi cara masyarakat mengkonstruksi dirinya, berkelakuan dan hubungan sosial mereka sebagai anggota masyarakat. Konstruksi diri disini dapat dikatakan sebagai sebuah identitas individu atau masyarakat.

Pada akhir tahun 2000-an situasi politik Indonesia mengalami perubahan yang amat dramatis. Banyak kebijakan lama dicabut dan kebijakan baru diperkenalkan. Di antara kebijakan tersebut adalah dicabutnya larangan terhadap unsur kesenian Cina. Pada tahun 2000, melalui Keppres No 6/2000, Presiden Abdurrahman Wahid mencabut Inpres No. 14/1967 dan membebaskan orang Cina untuk merayakan hari besar dan adat serta tradisi mereka. Setelah terpasung selama hampir setengah abad, Barongsai secara tiba-tiba mencuat ke permukaan. Kelahirannya merupakan fungsi situasi politik dari periode reformasi pada pertengahan 1990-an (Shahab, 2003).

Berbeda dengan barongsai, gambang kromong yang merupakan budaya akulturasi tidak mengalami 'kematian' saat diberlakukannya Inpres No. 14/1967. Gambang kromong yang cikal-bakalnya dari etnis Cina merupakan contoh musik yang sudah beradaptasi dengan lingkungannya. (Kompas, 3 Februari 2003).

Tulisan ini memberikan gambaran tentang bertahannya kesenian dalam sebuah masyarakat dimana perkembangannya dipengaruhi oleh kondisi lingkungan sekitar masyarakat tersebut. Kondisi ini dapat berupa keadaan politik yang bergejolak pada saat tertentu. Hal ini yang berlaku untuk gambang kromong yang dimiliki oleh orang Cina Benteng, Inpres No 14 tahun 1967 tidak berpengaruh terhadap gambang kromong di Tangerang?

\section{METODE PENELITIAN}

Tulisan ini menggunakan pendekatan kualitatif dalam bentuk studi kasus yaitu gambang kromong Sinar Gemilang. Gambang kromong Sinar Gemilang sendiri dipimpin oleh seorang keturunan Cina bernama Sauw Ong Kian. Penggalian data yang lengkap mengenai kelompok gambang kromong ini ditujukan untuk mendapatkan gambaran tentang fungsi gambang kromong bagi keberadaan Orang Cina Benteng sebagai pemilik kesenian.

Penelitian ini menggambarkan dampak peraturan terhadap bertahannya kesenian yang dimiliki oleh Orang Cina Benteng. Deskripsi mendalam juga menjelaskan makna 
gambang kromong dalam praktek kehidupan orang Cina Benteng serta posisi gambang kromong sebagai unsur kesesian dalam kebijakan politik idenstitas.

Wawancara sebagai teknik utama dalam metode penelitian, dilakukan kepada informan yang diambil secara sengaja berdasarkan pertimbangan guna mendalami kasus serta pemahaman masalah. Informan kunci dalam penelitian ini adalah pemimpin kelompok gambang kromong Sinar Gemilang. Informan selanjutnya ialah David Kwa pemerhati budaya Cina Peranakan dan Oey Tjin Eng, Tokoh Cina Benteng dan pengurus kelenteng Boen Tek Bio. Data yang diperoleh kemudian dilakukan analisis dengan menggunakan kualitatif deskriptif.

\section{HASIL DAN PEMBAHASAN}

\section{Gambang Kromong di Tangerang}

Orang Cina Benteng merupakan varian dari etnis Cina di Indonesia. Orang Cina Benteng dalam penelitian ini mengacu pada orang Cina Benteng yang tinggal di lokasi penelitian yaitu di Tangerang. Ethnic group atau sukubangsa terbentuk karena adanya ciri yang ditentukan oleh kelompok itu sendiri, yang kemudian membentuk pola tersendiri dalam hubungan interaksi antara sesamanya (Barth 1988: 11). Dengan kata lain bahwa ciri ini membentuk identitas yang digunakan oleh anggota suatu masyarakat untuk membedakan dengan masyarakat yang lainnya. Wujud identitas itu, misalnya bahasa, tempat tinggal, pola kekerabatan, pola perkawinan, religi, kesenian, arsitektur rumah, pola tempat tinggal dan lain-lain.

Orang Cina Benteng merupakan potret kelompok yang secara budaya telah berintegrasi dengan pribumi (Kompas, 5 Januari 2004). Mereka tidak lagi merasa eksklusif, tetapi sudah meyakini menjadi bagian integral dari bangsa Indonesia. Karakteristik orang Cina Benteng ini unik, jika melihat kondisi fisik pastilah tidak dapat membedakan dengan pribumi. Fisik orang Cina Benteng menyerupai pribumi, yaitu berkulit hitam dan mereka tak mampu berkomunikasi dalam bahasa Cina.

Orang Cina Benteng tidak seperti orang Cina yang selama ini ada dalam pandangan umum (Witanto, 2004: 5). Mereka bukanlah pebisnis yang sukses atau pemilik perusahaan raksasa. Identitas mereka dengan adat dan tradisi masih kuat sebagian besar orang Cina di Indonesia memandang orang Cina Benteng sebagai lower status. Identitas sebagai gagasan tentang siapakah "kita" (who we are) dan bagaimana secara aktif berhubungan dengan "mereka yang bukan kita" (the others). Identitas merupakan bagian dari konsep diri individu. Identitas seseorang adalah nama yang ia pakai untuk menyebut diri (self)-nya sendiri. Dalam hal ini kategorisasi self dan Other tergantung pada siapa, berhubungan dengan apa dan dalam konteks yang bagaimana. Dengan kata lain Woodward menyatakan bahwa identitas dapat merupakan proses pengidentifikasian dan penempatan posisi seseorang atau sekelompok orang dalam sebuah konteks tertentu. (Woodward 1997: 14). Gambang kromong yang dimiliki oleh orang Cina Benteng sebagai tradisi kultural mereka memiliki ciri yang membedakan dengan etnik lain sehingga gambang kromong ini dapat disebut gambang kromong orang Cina Benteng.

Keunikan orang Cina Benteng adalah bahwa mereka telah berakulturasi dan beradaptasi dengan lingkungan dan kebudayaan lokal. Keseharian mereka berbicara logat sunda pinggiran bercampur Betawi. Hal ini sejalan dengan pendapat Koentjaraningrat (2009: 202) mengenai akulturasi yang merupakan suatu proses sosial yang timbul bila suatu kelompok manusia dengan suatu kebudayaan tertentu dihadapkan dengan unsurunsur dari suatu kebudayaan asing dengan sedemikian rupa sehingga unsur-unsur 
kebudayaan asing itu lambat laun diterima dan diolah kedalam kebudayaan sendiri tanpa menyebabkan hilangnya kepribadian kebudayaan itu sendiri.

Nama Benteng sendiri merupakan nama lama dari Kota Tangerang. Di pusat kota Tangerang dahulu terdapat Benteng Makassar yang dibangun pada jaman kolonial Belanda. Sekarang benteng tersebut sudah rata dengan tanah, letaknya di tepi sungai Cisadane. Sejak tahun 1700-an orang Cina Benteng yang kurang mampu, tinggal di luar Benteng Makassar. Mereka tinggal kebanyakan di daerah sebelah utara yaitu di Sewan dan Kampung Melayu.

Banyaknya orang Cina yang tinggal di pedesaan yakni diluar pecinan di Pasar Lama dan Pasar Baru terkait dengan terjadinya pemberontakan pada tahun 1740. Saat itu Gubernur Jenderal Valkenier mengeluarkan keputusan untuk menangkapi orang-orang Cina yang dicurigai. Mereka akan dikirim ke Sri Lanka untuk dipekerjakan di perkebunan-perkebunan milik VOC. Pemberontakan itu dibalas serangan serdadu kompeni ke perkampungan-perkampungan Cina di Batavia (Jakarta). Sedikitnya 10.000 orang tewas dan sejak itu banyak orang Cina mengungsi untuk mencari tempat baru di daerah Tangerang, seperti Mauk, Serpong, Cisoka, Legok, dan bahkan sampai ke Parung daerah Bogor. Meski demikian mereka yang tinggal diluar Pasar Lama dan Pasar Baru tetap disebut orang Cina Benteng. (Adi, 2003).

Orang Cina Benteng masih mempertahankan dan melestarikan adat istiadat nenek moyang yang sudah ratusan tahun. Hal tersebut tampak pada keberadaan meja abu di setiap rumah orang Cina Benteng, tata cara upacara perkawinan dan kematian, serta tradisi leluhur yang masih dipertahankan antara lain Cap Go Meh, Pek Cun, Tiong Ciu Pia (kue bulan), dan Pek Gwee Cap Go (hari kesempurnaan). Demikian pula panggilan encek, encim, dan engkong digunakan sebagai tanda hormat kepada orang yang lebih tua. Bagi orang Cina Benteng gambang kromong adalah bagian dari kesehariannya. Kesenian tradisional ini sangat populer, setiap pesta perkawinan bisa dipastikan diramaikan dengan gambang kromong sebagai hiburan utama (Kompas, 3 Februari 2003). Sebab, gambang kromong yang dimainkan dalam pesta-pesta perkawinan, umumnya diwarnai tari cokek yang sebenarnya merupakan budaya tayub masyarakat Sunda pesisir seperti Indramayu. (Adi, 2003).

Gambang kromong digunakan untuk mengiringi cokek yaitu jenis tarian untuk menghibur tamu sebagai pemeriah pesta pernikahan orang Cina. Istilah cokek digunakan untuk menyebut penari wanita yang pada waktu itu rambutnya di-cocang (dikepang) dan mengenakan ciang hi yaitu pakaian yang banyak digunakan oleh wanita Cina. Cokek menari dengan tamu pria dalam jarak tertentu, sehingga masih disebut "sopan", sedangkan cokek sekarang menari dalam pelukan tamu pria. Dalam perkembangan selanjutnya ciang hi tidak dipakai lagi digantikan dengan kain dan kebaya, sedangkan rambut yang dicocang tidak lagi dikenal, digantikan dengan sanggul (Kleden, 1996: 50$51)$.

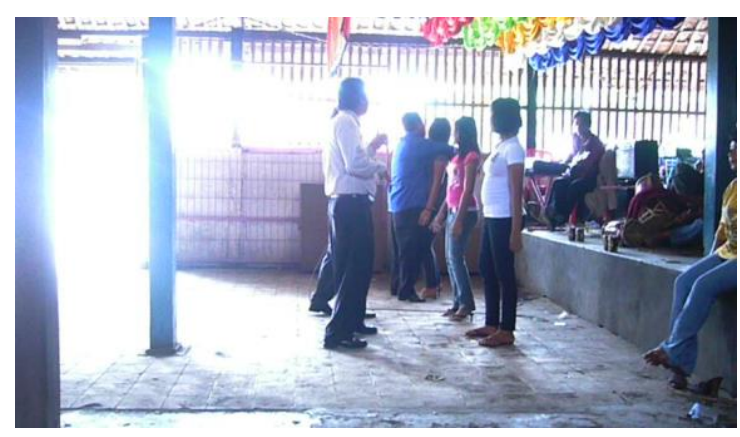

Gambar 1 Tampilan cokek 
Tampak pada gambar 1 merupakan tampilan cokek saat ini dimana lak-ilaki dan perempuan menari berhadapan. Para penari cokek sudah tidak lagi mengenakan kain dan kebaya dengan rambut disanggul, supaya lebih praktis mereka menggunakan kaos dan celana jeans, dengan wajah yang dipoles sedemikian rupa sehingga terlihat putih seperti porselen. Orang Tangerang mengatakan tari cokek ini dengan nama lain ngibing, sedangkan para laki-lakinya disebut orang pelesiran, atau orang yang mencari hiburan dengan menari dengan ditemani perempuan-perempuan cantik. Saat menari ini para kaum laki-laki keturunan atau yang disebut empek-empek memberikan uang kepada penari cokek sebagai saweran, semakin malam tarian yang diiringi musik gambang kromong ini akan semakin ramai. Guna meramaikan suasana di beberapa rumah pesta terdapat warung yang menjual minuman beralkohol yang dikonsumsi oleh empek-empek. Biasanya para penari cokek ini pun ikut minum supaya uang saweran yang dari empek-empek ini banyak diperoleh, karena menuruti semua kemauan empek-empek ini.

“...oh tentang gambang kromong, kan ada cokeknya... heheheheh...tari cokek itu dibilang tari berhimpit, laki-laki sama perempuan nari deket-deketan sampe berhimpitan, itu ciri khas tari cokek dan gambang kromong disini” Kata Bapak Alfon

Penyelenggaraan gambang kromong oleh kelompok-kelompok gambang kromong yang "ditanggap" adalah saat pesta pernikahan, Cap Go Meh, ataupun perayaan hari ulang tahun kelenteng atau kebanyakan orang Cina Benteng mengatakan shedjit. Adanya berbagai perayaan yang melibatkan gambang kromong sebagai hiburan menjadikan grupgrup gambang kromong di Tangerang masih ada hingga sekarang.

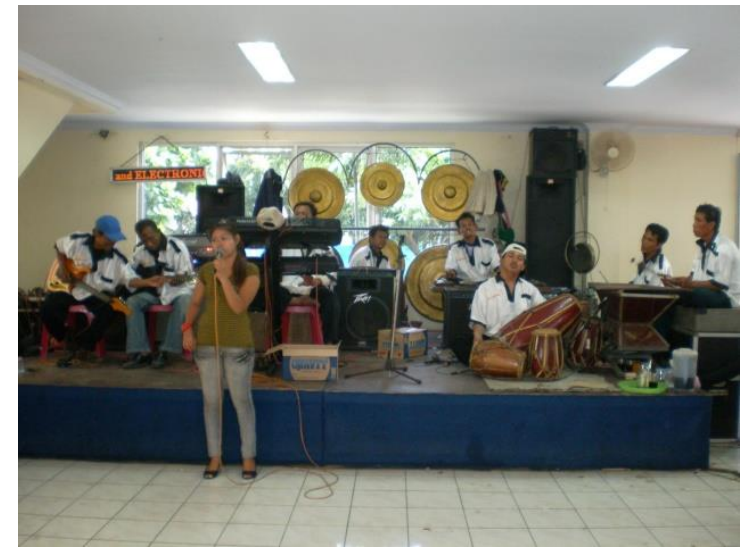

Gambar 2 Pertunjukan gambang kromong saat pesta pernikahan

Menurut penuturan Bapak Adang:

“...di Tangerang sini kira-kira ada dua puluhan grup gambang kromong. kayak paguyuban gitu? Disini gak ada...cuman ya itu ada sekitar dua puluhan grup yang sampe sekarang masih ada di Tangerang dan masih sering di tanggap orang pesta. Kalo guyuban disini mah belum ada."

Pada saat penelitian dilakukan mayoritas pertunjukan gambang kromong diselenggarakan saat pesta pernikahan. Di Tangerang bagian utara sendiri sebagai daerah penelitian, penyelenggaraan pesta pernikahan di rumah pesta atau rumah kawin. Di dalam rumah kawin tersebut terdapat panggung yang biasanya berada disebelah kanan pintu masuk utama. Panggung inilah yang digunakan grup gambang kromong untuk pertunjukan. 
Orkes gambang semula hanya digemari oleh kaum peranakan Cina saja, karena berlangsungnya proses pembauran lama kelamaan di gemari pula oleh golongan pribumi. Orkes gambang merupakan perkembangan dari orkes Yang Khim yang terdiri atas YangKhim, sukong, hosiang, thehian, kongahian, sambian, suling, pan (kecrek) dan ningnong. Oleh karena Yang-Khim sulit diperoleh, maka digantilah dengan gambang yang larasnya di sesuaikan dengan notasi yang diciptakan oleh orang-orang Hokkian. Sukong, tehian dan kongahian tidak begitu sulit untuk dibuat disini, sedangkan sambian dan hosiang di tiadakan tanpa terlalu banyak mengurangi nilai penyajiannya.

Sekitar tahun 1880 atas usaha Tan Wangwe dengan dukungan Bek (Wijkmeester) Pasar Senen Teng Tjoe, Orkes Gambang mulai dilengkapi dengan Kromong, Kempul, Gendang, dan Gong. Lagu-lagunya ditambah dengan lagu Sunda Popular. Sejak itulah dikenal dengan nama orkes Gambang Kromong. Bila pada masa lalu popularitas orkes gambang kromong umumnya hanya terbatas dalam lingkungan masyarakat keturunan Cina dan masyarakat yang langsung atau tidak langsung banyak menyerap pengaruh kebudayaannya (Ruchiat, dkk, 2003: 21).

Perkembangan kesenian ini selanjutnya tidak hanya di daerah Jakarta saja tapi juga ke daerah Bekasi, Bogor, Depok, dan Tangerang yang dahulunya sebagai tempat pelarian orang Cina saat terjadi pembantaian tahun 1740 maupun saat jaman VOC Hindia-Belanda saat itu, terlebih di daerah Tangerang dimana terdapat orang Cina Benteng yang mendiami Tangerang hingga ke pelosok. Grup gambang kromong banyak terdapat di daerah dengan banyak penduduk keturunan Cina seperti di Tangerang. Hal ini seperti yang dikatakan David Kwa:

"...gambang kromong bukan seperti sangkaan orang, berasal dari kesenian orang Cina Benteng. Awalnya muncul di Jakarta, menyebar ke Barat yakni Tangerang, daerah Selatan pada komunitas Tionghoa di Bogor, Cileungsi, Jonggol, Ciampea, sampe Gunung Sindur. Daerah timur pada komunitas Tionghoa Bekasi daerah Babelan, Teluk Buyung, Teluk Angsa."

Tangerang sendiri dijadikan sebagai daerah penyangga pangan dan bidang pertanian bagi perlindungan kota Jakarta sudah sejak pemerintahan Hindia Belanda mulai abad 18. Letaknya yang relatif dekat dengan kota Jakarta menyebabkan Tangerang tidak lepas dari pengaruh kota Jakarta. Pertunjukan gambang kromong sendiri pada masa diberlakukannya Inpres No 14 tahun 1967 masih dapat terus dilaksanakan bersamaan dengan dilakukannya tradisi-tradisi orang Cina Benteng itu sendiri. Tradisi-tradisi ini masih mereka jalankan karena masih seiring dengan pemberlakuan Inpres saat itu dimana pelaksanaannya pada tataran pribadi. Walaupun bersifat komunal dan melibatkan orang banyak pada pelaksanaan tradisi ini namun lingkup penyelenggaraannya masih dalam tataran keluarga yang bersatu dalam satu wilayah kekerabatan atau yang mereka sebut kongsi.

\section{Fungsi Pertunjukan Gambang Kromong}

Pada awalnya musik gambang kromong ini digelar saat diadakan pesta atau perhelatan yang bersifat kegembiraan, atau untuk membayar nadzar tertentu. Tidak ada fungsi khusus dari pertunjukan gambang kromong yang berkaitan dengan kepercayaan pendukung kesenian ini. Gambang kromong adalah bentuk dari kesenian yang berfungsi untuk menghibur tuan rumah acara maupun para tamu yang hadir dalam acara, perayaan, atau pesta tertentu.

Fungsi kesenian sebagai hiburan ini merupakan salah satu kebutuhan manusia. Kebutuhan untuk beradab yang bercorak atau integratif, yakni mengintegrasikan berbagai 
unsur kebudayaan menjadi satu satuan sistem dan masuk akal bagi para pelakunya. (Suparlan, 2004). Fungsi lain yang nantinya dapat muncul berkaitan dengan keberadaan orang Cina Benteng sebagai masyarakat pendukung kesenian ini.

Pertunjukan gambang kromong saat ini tidak terlepas dari 3 unsur di dalamnya. Yakni pemain musik (panjak), Penyayi, dan Penari cokek. Kelompok-kelompok gambang di Tangerang sudah jarang yang memainkan gambang klasik atau asli, kebanyakan dari kelompok-kelompok ini memainkan gambang kromong kombinasi. Saat digelarnya pertunjukan ada kalanya dinyanyikan lagu-lagu untuk ngibing biasanya dimainkan lagulagu dangdut, sedangkan lagu gambang kromong seperti Phobin bukan lagu untuk ngibing. Saat pertunjukan gambang kromong berjalan dengan dimainkan lagu dangdut misalnya para penari mulai beranjak dari kursi duduk mereka, terlebih ketika empekempek mengangkat cukin penanda mulai ngibing. Sepenuhnya para penari cokek yang mendampingi empek-empek menari harus menuruti kemauan si pemberi sawer. Dari meraba, memeluk, mencekoki minuman keras atau bahkan sampai keatas ranjang. Namun, kalau sampai keatas ranjang biasanya tarif dipatok oleh para mami yang membawa penari cokek tersebut.

Satu kelompok gambang kromong mempunyai 10-12 penari, tapi terkadang ketika satu kelompok gambang kromong main dengan para penarinya, penari "pendatang" ikut juga mencari peruntungan bukan di tempat kelompoknya. Penilaian bagus tidaknya suatu pertunjukan gambang kromong oleh kelompok gambang kromong tertentu bukan hanya dari permainan alat musik dan suara penyanyi yang dianggap resep didengar atau mahalnya tarif sewa gambang, tetapi juga penilaian untuk para penari dari kelompok tertentu yang dianggap jogetnya enak.

\section{Pertunjukan Gambang Kromong Sinar Gemilang}

Pertunjukan gambang kromong Sinar Gemilang secara menyeluruh dapat dilihat dari tata letak alat musik di atas panggung, busana pentas, dan yang terakhir ritual ngukup. Pertama, Mengenai tata letak alat musik diatas panggung diserahkan sepenuhnya oleh tukang panggul Sinar Gemilang yang juga merangkap sebagai pemain kecrek dan pengontrol suara yang keluar dari alat pengeras yakni Bang Tukul dan Adi. Penempatan seluruh alat musik dan sound system sudah ada tempatnya masing-masing. Walaupun dipanggung yang berbeda penempatan alat musik pasti sama. Dari pertunjukan yang diselenggarakan di waktu dan tempat yang berbeda penempatan alat musik oleh Bang Tukul diletakan ditempat yang sama.

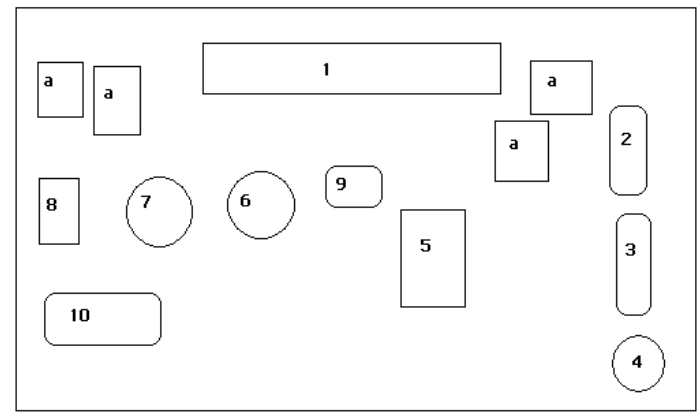

Gambar 3 Penempatan alat music gambang kromong sinar gemilang

Keterangan Gambar:
1. Gong Enam
a. Pengeras Suara
2. Kromong
3. Gambang 


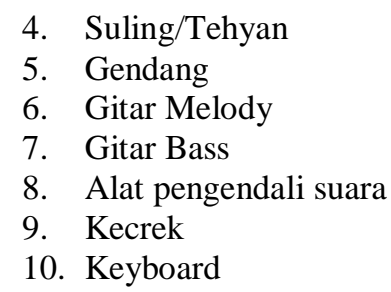

Dari pertunjukan Sinar Gemilang di tempat dan waktu yang berbeda, penempatan alat musik seperti inilah yang dipakai Bang Tukul. Bang tukul sudah hafal benar letakletak alat musik yang harus dia taruh. Dibantu Adi dia memasang jack dan kabel aliran listrik yang menghubungkan ke alat pengeras suara.

Tugas Bang Tukul ini mengambil alat-alat musik dari rumah Bapak Ong Kian ke panggung pertunjukan dan meletakkannya seperti biasa. Misalnya ketika pertunjukan gambang kromong dimulai pukul 19.30 Bang Tukul sudah siap di panggung pertunjukan untuk meletakkan alat mulai pukul 11.00. Alat-alat sudah selesai ditempatkan dan siap dimainkan pada pukul 16.00. Pekerjaan meletakan alat musik ini juga dibantu oleh Bapak Minggu pemain gong. Dia Bertugas memasang kain-kain satin berwarna cerah sebagai hiasan panggung dan tak lupa spanduk yang terbuat dari kain bludru berwarna jingga sebagai tanda pengenal gambang kromong Sinar Gemilang dengan disertakan nama pemimpin gambang kromong Sinar Gemilang dalam lafal Cina yakni Sauw Ong Kian. Berikut adalah gambar-gambar letak alat musik gambang kromong Sinar Gemilang dalam waktu pertunjukan dan tempat yang berbeda.

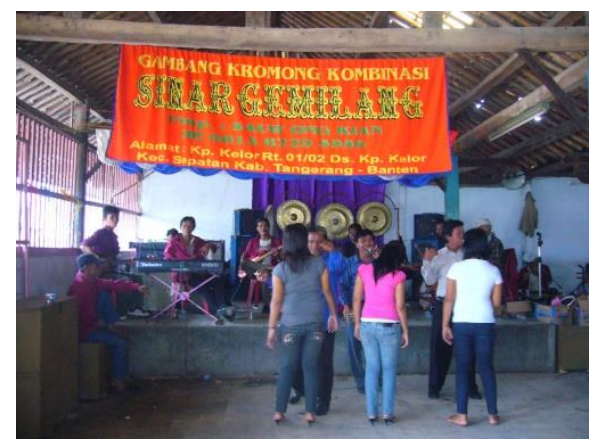

Gambar 4 Tampak depan pertunjukan gambang kromong sinar gemilang di rumah kawin Iyok

Tampak dalam gambar 4 sampai gambar 5 alat musik gambang, gong enam, keyboard pemain bass dan gitar melody berada seperti pola.

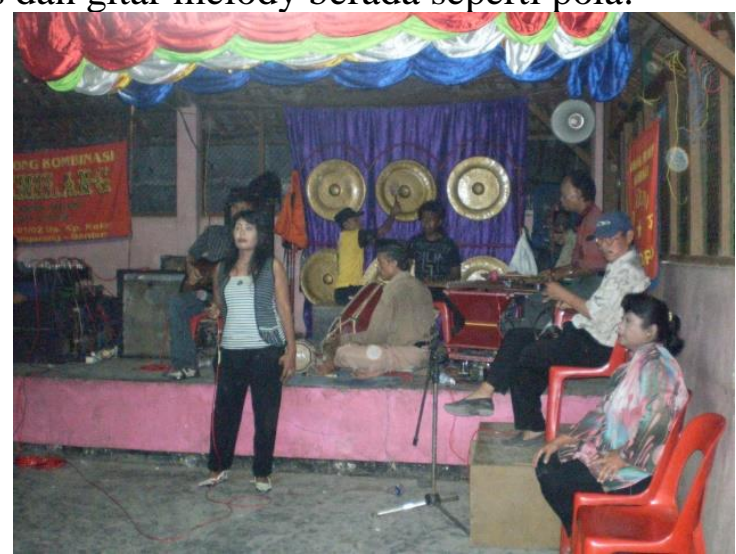

Gambar 5 Tampak depan pertunjukan gambang kromong sinar gemilang di rumah kawin Cun Wat. 


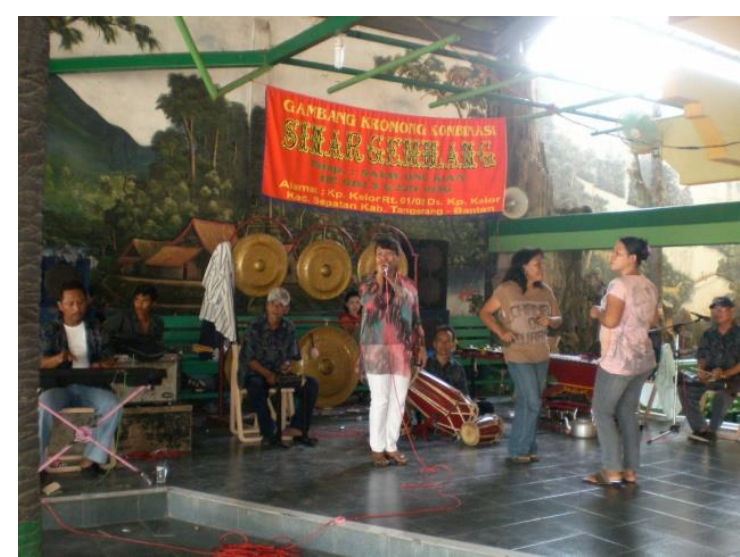

Gambar 6 Tampak samping pertunjukan gambang kromong Sinar Gemilang di rumah kawin hengki.

Dari ketiga gambar tersebut terlihat penempatan alat musik dari panggung yang satu ke panggung lainnya berada ditempat yang sama. Hal ini dikarenakan seringnya gambang kromong Sinar Gemilang menggelar pertunjukan. Bang Tukul mengatakan sudah hafal betul letak alat musik yang harus dia taruh. Tidak ada kesulitan yang berarti sebab Bang Tukul sendiri sudah hampir 10 tahun bergabung dengan Sinar Gemilang, menurut Bang Tukul:

"Atuh mau panggung yang kecil mau panggung yang gede, naruh alatnya ya

begini. Gong mah ditaro dibelakang."

Penyanyi dan penari penempati bagian depan panggung yang kosong. Apabila panggung kecil seperti di rumah kawin Iyok dan Cun Wat penari dan penyanyi menjadi satu di bawah panggung tidak berada diatas panggung. Panggung besar dan lebar seperti di rumah kawin Hengki semua penari, penyanyi dan panjak gambang berada diatas panggung.

Kedua, mengenai busana pentas yang dipakai oleh pemain musik, panyanyi, dan penari. Dalam gambar 4 dan 6 pemain musik memakai kemeja yang motif dan warnanya sama. Kemeja ini sengaja dibeli oleh Bapak Ong Kian sebagai seragam pemain musik Sinar Gemilang. Seragam ini digunakan pada hari pesta kedua acara pernikahan orang Cina di Tangerang. Malam pertunjukan pertama seperti pada gambar 5 para pemain musik tidak memakai seragam. Pada malam itu biasanya setelah selesai pertunjukan disepakati busana apa yang hendak dipakai untuk esok harinya. Busana yang dipakai para penyanyi dan penari tidak ditentukan seperti para panjak. Busana penyanyi mereka sendiri yang menyiapkan begitupula penari. Namun, dalam pertunjukan gambang kromong pada acara-acara tertentu para penyanyi dan penari ini memakai kebaya dan kain batik. Hal ini disesuaikan dengan permintaan tuan rumah atau penaggap gambang kromong.

Dari pengamatan yang lakukan, busana penyanyi dan penari saat pertunjukan Sinar Gemilang dalam pesta pernikahan orang Cina Benteng mereka memakai kaos ketat dan celana jeans. Alas kaki berhak 3-5 cm mereka gunakan untuk melengkapi penampilan mereka. Dari pengamatan ini, jarang sekali ditemukan para penari dan penyanyi yang masih menggunakan kebaya. Orang yang masih menggunakan kebaya saat upacara pernikahan adat Cina biasanya adalah juru rias pengantin, orang yang menuntun upacara pernikahan.

Tahap ketiga, setelah semua alat diletakkan sesuai tempatnya dan siap untuk menggelar pertunjukan diadakan ritual ngukup. Ritual ini dilakukan oleh pemilik gambang kromong atau keturunannya. Ngukup sendiri adalah kegiatan membuat asap 
dengan membakar kemenyan sambil memanjatkan doa untuk kelancaran, keselamatan serta kesuksesan selama pertunjukan dilakukan. Ketika asap kemenyan sudah mengepul alat-alat pemukul gambang, kromong, gong dipegang oleh pemilik gambang, seluruh alat pemukul ini harus terkena asap kemenyan. Selain itu juga ada sesaji yang harus disediakan oleh orang yang punya hajat untuk ritual ngukup ini selain kemenyan. Sesaji tersebut adalah telur, lisong, sirih, kopi manis dan pahit, teh manis dan pahit, rujak asem, limun (sekarang diganti dengan Ale-Ale), rokok 4 macam, kue-kue yang disajikan saat acara pesta pernikahan, dan air putih.

Bapak Ong Kian melakukan ngukup, apabila pertunjukan Sinar Gemilang akan dilaksanakan. Mulai Ngukup pukul 17.00 setelah alat-alat selesai diletakkan dan siap dimainkan. Kemenyan dan sesaji lainnya ditaruh dibawah alat gambang, begitu kemenyan ditaburkan asap mengepul Pak Ong Kian mengumpulkan semua alat pemukul dan mengasapkan alat-alat tersebut dengan membaca doa-doa. Tanda selesainya ritual ini adalah ketika gong dibunyikan dengan pemukul yang terlebih dahulu diasapi. Setelah ngukup selesai tinggal menunggu panjak gambang, penyanyi, dan penari berkumpul datang ke tempat pertunjukan.

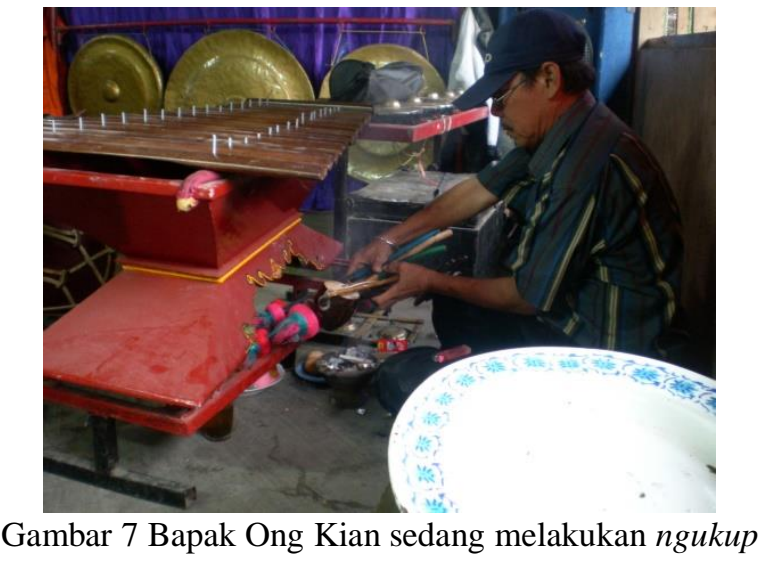

Ngukup merupakan suatu kepercayaan yang diyakini oleh Bapak Ong Kian untuk memperoleh keselamatan saat menggelar pertunjukan gambang kromongnya. Ia mempercayai apabila dia tidak melakukan ngukup sebelum dimulainya pertunjukan gambang kromong akan ada gangguan dan tidak lancarnya pertunjukan. Selama ia menjadi pemimpin gambang kromong Sinar Gemilang tidak pernah sekalipun ia tidak melakukan ngukup. Bapak Ong Kian sudah dapat melakukan ngukup sejak dia belum menjadi pemimpin Sinar Gemilang, atau saat dia masih bermain pada gambang kromong Rindu Malam milik ayahnya.

\section{Gambang Kromong Sebagai Penguat Identitas Cina}

Pasca Reformasi dalam penelitian ini ditandai dengan dicabutnya Instruksi Presiden No. 14 Tahun 1967. Melalui Keppres No 6/2000, Presiden Abdurrahman Wahid mencabut Inpres dan membebaskan orang Cina untuk merayakan hari besar dan adat serta tradisi mereka. Pada saat pemberlakuan Inpres tersebut, orang Cina tidak diijinkan untuk menyelenggarakan hari raya Imlek, Cap Go Meh dan lainnya maupun mempertahankan tradisi ritual dimuka publik. Dampak dari keputusan ini menjadikan orang Cina semakin kehilangan identitasnya dikalangan masyarakat Indonesia. Kebudayaan Cina seperti Barongsai, Liong, Wayang Potehi dan kebudayaan Cina lainnya menjadi sangat terbatas penampilannya di Indonesia. 
Orang Cina di sini merupakan suatu ethnic group, yang artinya mereka sebagai suatu kumpulan manusia terbentuk karena adanya ciri yang ditentukan oleh kelompok itu sendiri. Mereka merasa memiliki perbedaan dengan ethnic group lain dengan ciri tersebut. Perbedaan ini tampak pada bahasa, tradisi, kesenian dan lainnya. Pada saat pemeberlakuan Inpres bahasa, tradisi, dan kesenian yang dimiliki oleh orang Cina dibatasi pelaksanaannya. Tidak hanya kesenian dan tradisi yang dirasa berasal dari tanah nenek moyang orang Cina, namun juga tradisi dan kesenian yang telah terkulturasi dengan kesenian asli Indonesia.

Terdapat perbedaan pemberlakuan Inpres terhadap kesenian Cina yang dianggap berasal dari tanah nenek moyang mereka dan kesenian yang terakulturasi. Seperti halnya barongsai yang "mati" selama pemberlakuan inpres, sedangkan gambang kromong sebagai kesenian akulturasi tidak mengalami hal tersebut. Akulturasi yang terbentuk dari unsur kesenian yang dimiliki orang Cina dan Betawi ini dijadikan sebagai upaya untuk mempertahankan kesenian gambang kromong sehingga tidak terkena pemberlakuan Inpres. Keunikan gambang kromong sebagai budaya akulturasi inilah yang dirasa harus terus dipertahankan.

Orang Cina sebagai suatu ethnic group dalam penulisan ini mengacu pada kategori orang Cina yang disebut oleh Leo Suryadinata sebagai orang Cina Peranakan. Mereka sudah tidak lagi dapat menggunakan bahasa Cina. Ethnic group ini merupakan hasil perkawinan campuran antara laki-laki pendatang Cina asli dengan wanita Pribumi dan cenderung mengidentifikasi diri berdasarkan daerah-daerah di Indonesia dimana mereka tinggal. Selain itu ciri fisik orang Cina ini yang bermata sipit dan berkulit putih juga digunakan untuk membedakan anggota suatu suku bangsa dengan anggota suku bangsa lainnya. Pada saat pemberlakuan Inpres ini, ciri fisik inilah yang digunakan untuk membedakan mana pribumi dan orang keturunan Cina, sehingga dapat dikatakan pemberlakuan peraturan ini diskriminatif terhadap orang keturunan Cina. Padahal mereka telah mengidentifikasi diri mereka berdasarkan tempat lahir dan tempat tinggal mereka di Indonesia dan telah diakui oleh negara sebagai Warga Negara Indonesia.

Pemberlakuan ini berakibat pada pengekangan terhadap lahirnya ekspresi berbagai identitas, termasuk identitas sebagai orang Cina atau singkatnya identitas etnik Cina. Ciri yang melekat pada etnik seperti misalnya bahasa, tempat tinggal, pola kekerabatan, pola perkawinan, religi, kesenian, arsitektur rumah ini yang akhirnya membentuk identitas.

Ciri dari kesenian gambang kromong yang dapat menunjukan bahwa kesenian ini adalah miliki orang Cina terdapat pada penggunaan alat-alat yang beasal dari negeri Cina yakni tehyan, kongahyan, dan sukong yang merupakan alat musik gesek. Pada perkembangan awal, alat musik Yang Khim yakni alat musik petik seperti kecapi masih digunakan. Namun akhirnya diganti dengan gambang yang bunyinya dapat disamakan dengan petikan alat musik tersebut.

Berdasarkan pada sejarah terbentuknya musik ini tidak dapat dilepaskan dengan jasa orang-orang Cina. Pada zaman kolonial Belanda yang karena kerinduannya terhadap negara asal, mereka memainkan alat musik gesek tersebut ditambah dengan alat musik yang berasal dari Indonesia seperti gambang, kromong, dan gong sehingga akhirnya menjadi musik gambang kromong. Lagu-lagu yang dimainkan seperti yang saat ini disebut lagu klasik memiliki istilah-istilah yang menggunakan bahasa Cina. Misalnya lagu Phobin yang terdiri Phobin Khong Ji Liok, Peh Pan Thau, Cu Te Pan, Cai Cu Siu, $\mathrm{Cai} \mathrm{Cu}$ Teng, Seng Kiok. Pada perkembangannya sekarang lagu-lagu klasik yang berbahasa Cina dan not 40 yang menggunakan aksara Cina sudah tidak dipakai lagi. Dikarenakan sudah semakin langkanya orang-orang yang dapat menyanyikan lagu 
tersebut dan terkait pula dengan pemberlakuan inpres tersebut. Hal ini sejalan dengan yang dikemukakan oleh David Kwa:

"Pemberlakuan Inpres tersebut telah menghilangkan satu generasi yang tercabut dari akar budayanya. Ini kelihatan dari udah tidak digunakan lagi nama orang berdasarkan penamaan terdiri dari 3 kata orang Tionghoa. Generasi muda ini tidak kenal lagi dengan kebudayaan Tionghoa."

Melihat pada kenyataan dampak pemberlakuan Inpres ini maka dapat dikatakan bahwa tidak ada lagi generasi muda yang dapat menyanyikan lagu-lagu klasik gambang kromong. Jika pun ada yang dapat menyanyikan adalah seorang yang sudah lanjut usia bernama Encim Masnah yang memiliki nama asli Pang Tjin Nio. Dia telah diakui oleh pemerintah pusat sebagai maestro gambang kromong. Namun demikian, walau lagu klasik sudah jarang diperdengarkan pada pertunjukan gambang kromong kebanyakan, lagu ini masih dinyanyikan oleh Encim Masnah saat Festival Peranakan di Singapura. Selain itu, lagu Ko'i atau lagu pop mandarin juga dinyanyikan dengan iringan musik gambang kromong. Hal ini menyiratkan bahwa gambang kromong lekat dengan orang Cina dan kebudayaannya. Selain itu, masih dimainkannya gambang kromong sebagai bagian dari tradisi orang Cina Benteng adalah pelaksanaanya yang dapat dikatakan masih dalam tataran pribadi, sehingga tidak terkena pemberlakuan Inpres.

Penyelenggaraan pertunjukan gambang kromong dalam tataran pribadi atau keluarga terkait dengan pola pemukiman orang Cina Benteng yang membentuk kongsikongsi yang didalamnya tinggal keluarga-keluarga yang masih berhubungan misalnya karena adanya pernikahan. Bentuk dari kongsi ini dapat merupakan wilayah rukun warga (RW).

Pertunjukan gambang kromong tidak terlepas dari tradisi-tradisi yang dilakukan oleh orang Cina. Tradisi tersebut meliputi pesta pernikahan orang Cina atau pernikahan adat Cina yang mereka sebut Cio Tao, perayaan hari ulang tahun kelenteng dan vihara atu shedjit, serta upacara kematian yang disertai dengan pembayaran kaul. Khususnya di Tangerang kelompok-kelompok gambang kromong dimiliki oleh orang keturunan Cina dan panjak yang juga orang keturunan Cina. Sehingga hal-hal tersebut diatas merupakan sebuah atribut yang digunakan untuk mengenali identitas atau jatidiri orang Cina. Dalam hal ini atribut adalah segala sesuatu yang terseleksi, baik disengaja maupun tidak, yang dikaitkan dengan dan untuk kegunaannya bagi mengenali identitas atau jati diri seseorang atau gejala. Atribut ini bisa berupa ciri-ciri yang menyolok dari benda atau tubuh orang, sifat-sifat seseorang, pola-pola tindakan, atau bahasa yang digunakan. (Suparlan, 2004b: 29).

Atribut-atribut ini yang digunakan oleh orang Cina untuk menjadikan gambang kromong sebagai kebudayaan mereka pasca reformasi. Perlu diketahui disini bahwa yang terjadi pada gambang kromong saat pemberlakuan Inpres adalah digunakannya identitas lain yang melekat pada gambang kromong sebagai bentuk budaya akultutasi yakni identitas Betawi, sehingga dapat dikatakan gambang kromong tidak terkena pemberlakuan Inpres tersebut. Saat pemberlakuan itu gambang kromong memiliki fungsi baru yakni untuk memperkaya identitas orang Betawi. (Danandjaja, 1987).

Setelah dicabutnya Inpres pertunjukan gambang kromong tidak lagi hanya sebatas perayaan pada HUT kota Jakarta, namun juga semakin banyak perayaan-perayaan Imlek yang mengundang kelompok gambang kromong untuk memeriahkan tahun baru Cina. Diakui kembali pernikahan adat Cina yang didalamnya terdapat pesta pernikahan yang dimeriahkan dengan gambang kromong dan cokek, semakin memperkuat identitas Cina. Selain itu, perayaan hari ulang tahun kelenteng dan vihara yang juga dimeriahkan oleh 
gambang kromong memperlihatkan bahwa kesenian ini tidak dapat dipisahkan dari tradisi orang Cina.

Gambang kromong sebagai sebuah kesenian telah memberikan identitas pada kelompok pemiliknya yakni orang Cina, yang pada gilirannya akan memperkuat eksisitensi ethnic group ini. Upaya-upaya agar gambang kromong tetap eksis sebagai kesenian orang Cina ialah dengan menggelarnya saat perayaan hari ulang tahun kelenteng dan vihara, perayaan imlek, ataupun saat perayaan pesta pernikahan Cio Tao. Pada gilirannya eksistensi ini akan mengundang pengakuan dari kelompok lain.

Proses identifikasi atau pengakuan gambang kromong sebagai kesenian orang Cina dilihat dari dua sisi, yakni proses identifikasi internal. Identifikasi ini berasal dari dalam anggota ethnic group ini yakni pemain musik gambang kromong keturunan Cina, Bapak Sauw Ong Kian pemilik gambang kromong Sinar Gemilang, pemerhati budaya peranakan Bapak David Kwa, dan ahli Cina Benteng Engkong Oey Tjin Eng.

"Ya ini kesenian orang Cina, alat musik yang dipake dari Cina sana...itu kongahyan, sukong, tehyan. Udah dari nenek moyang saya dulu mainin musik ini di kelenteng, cio tau, dan upacara kematian orang cina, ada juga yang kaulan. Kalo di Tangerang sini gak resep kalo gak mainin musik gambang waktu cio tau ato sejit" Kata Bapak Ong Kian

Sebagai orang Cina keturunan, mereka mengakui bahwa gambang kromong adalah kesenian mereka. Seperti Engkong Tjin Eng yang mengaku bahwa Ayah kandungnya dahulu adalah penggila cokek. Dimana ada pertunjukan gambang kromong disana dia ada untuk ngibing bersama cokek, sedangkan Bapak David Kwa adalah pemerhati budaya peranakan yang juga telah diakui sebagai budayawan Betawi oleh Lembaga Kebudayaan Betawi (LKB). Ini juga yang diakui oleh Yahya Andi Saputra, seorang budayawan Betawi:

“...David Kwa mah udah dianggap orang Betawi kok, kalo dia merasa orang cina sekarang ya gak apa-apa, itu mah hak dia"

Salah satu usaha yang telah dilakukan oleh Bapak David Kwa sebagai upaya pengakuan gambang kromong sebagai kesenian orang Cina adalah diterbitkannya buku "Peranakan Tionghoa Indonesia: Sebuah Perjalanan Budaya". Pendokumentasian ini dimaksudkan agar gambang kromong juga diakui sebagai kesenian Cina peranakan oleh para pembaca buku tersebut yang asalnya bukan hanya dari etnik Cina tapi dari etnik lainnya.

Identifikasi eksternal terjadi ketika seseorang atau kelompok orang mengidentifikasi orang lain sebagai apapun di luar dirinya atau kelompoknya. Identifikasi ini dilakukan oleh orang-orang diluar anggota enik Cina yang mengakui bahwa gambang kromong juga merupakan kesenian orang Cina dengan atribut yang melekat dalam gambang kromong yang membedakan dengan gambang kromong lainnya. Seperti telah dijelaskan sebelumnya bahwa atribut tersebut meliputi waktu dan tempat digelarnya pertunjukan yang diikuti oleh tradisi-tradisi Cina, lagu-lagu berbahasa Cina yang dimainkan, dan terdapatnya cokek saat pertunjukan. Seperti pengakuan seorang staff Lembaga Kebudayaan Betawi, Bapak H. Muhidin sebagai berikut:

"...gambang kromong asal musiknya dari Cina. Ini kesenian Cina kalo bisa dibilang, tapi kebanyakan pemain musiknya dari kita jadi gak kena cekal. Kalo Barongsai kena cekal itukan ritual jadi dianggap musyrik karena masyoritas penduduk Islam." 
Pak Roy staff kelurahan Mekarsari sebagai orang diluar etnik Cina mengidentifikasi gambang kromong ini dengan melihat saat digelarnya pertunjukan, siapa pemilik gambang kromong, dan adanya cokek sebagai komponen gambang kromong.

"Kalo gambang kromong di Betawi gak ada cokeknya, disini kebanyakan ada cokek yang identik sama orang yang plesiran biasanya empek-empek atau orang Cina yang udah tua yang pada ngibing."

Penggunaan simbol-simbol dari segala aspek budaya orang Cina merupakan suatu identitas untuk membedakan mereka dengan kelompok lainnya. Ethnic group Cina ini memiliki persamaan tradisi kultural yang tidak dimiliki oleh group yang lainnya. Tradisi ini meliputi:

1. Praktek keagamaan dengan mengacu pada rumah ibadah mereka yakni kelenteng dan vihara dan agama Budha, Tao, dan Konghucu yang banyak dianut oleh orang Cina.

2. Bahasa, dimana kebanyakan orang Cina Peranakan sudah tidak bisa lagi bahasa Cina secara fasih. Tapi masih menggunakan istilah-istilah Cina yang dicampur istilah setempat sehingga memiliki ciri khusus. Hal ini digunakan untuk mengidentifikasi orang Cina yang telah membaur dengan masyarakat setempat.

3. Perjalanan sejarah bersama

4. Nenek moyang yang sama dan leluhur yang sama.

5. Tempat asal usul yang sama yakni di Cina.

Lima batasan dasar inilah yang digunakan untuk mengidentifikasi orang Cina di Tangerang sebagai pemilik kesenian gambang kromong. Serta yang membedakan dengan gambang kromong yang dimiliki oleh etnik Betawi.

Dicabutnya Inpres memberikan kesadaran kepada anggota etnis keturunan Cina seperti Bapak David Kwa dan Engkong Tjin Eng untuk kembali mengakui gambang kromong sebagai kesenian Cina Peranakan. Seperti halnya yang terus dilakukan oleh Pak Ong Kian yang disadari atau tidak sebagai seniman yang telah melestarikan gambang kromong dengan terus menggelar pertunjukan dengan tidak terlalu memusingkan keadaan politik yang terjadi.

Digelarnya pertunjukan saat perayaan-perayaan hari besar Cina merupakan indikator awal pengakuan kesenian ini sebagai kesenian Cina yang datang dari anggota ethnic group maupun dari luar. Pengakuan ini akan memperkuat eksistensi orang Cina, sehingga pada akhirnya orang Cina dapat mempertahankan kelompoknya, dengan pengungkapan dan pengukuhan yang terus menerus melalui digelarnya pertunjukan gambang kromong tersebut.

\section{SIMPULAN}

Tradisi-tradisi Cina yang sempat dicekal pada masa orde baru tidak memberikan pengaruh yang besar bagi perkembangan gambang kromong. Gambang kromong sebagai atribut etnis Cina Benteng dapat terus bertahan ditengah situasi politik yang mendiskriminasi etnik Cina di Indonesia dengan diberlakukannya berbagai kebijakan yang pada saat itu dipercaya untuk menciptakan stabilitas nasional. Atribut budaya yang membedakan orang Cina Benteng dengan etnik lainnya yang hingga saat ini masih dipertahankan berupa nama keturunan Cina berdasarkan tiga huruf berbahasa Cina, tradisi Cina, peninggalan sejarah seperti rumah tradisional keturunan Cina, pemakaman, dan gambang kromong. Gambang kromong digunakan untuk menyampaikan pesan kepada penikmat bahwa mereka adalah orang Cina Benteng yang membutuhkan pengakuan akan keberadaan mereka. 
Pasca Reformasi yakni ditandai dengan kembali diperbolehkannya pelaksanaan perayaan-perayaan hari besar Cina dan pelaksanaan upacara pernikahan adat Cina, melalui pertunjukan gambang kromong Sinar Gemilang pimpinan Bapak Ong Kian berupaya menampilkan identitas kecinaan. Dengan membangun pengakuan kepada penikmat gambang kromong bahwa kesenian ini juga milik orang Cina Benteng yang akhirnya juga pengakuan atas keberadaan orang Cina Benteng itu sendiri.

Pengakuan ini berasal dari dalam maupun dari luar atau proses identifikasi internal dan eksternal. Identifikasi internal terjadi dari dalam orang Cina Benteng yang mengakui pertunjukan gambang kromong dalam tradisi Cina yang mereka jalankan adalah miliki Cina Benteng. Orang-orang diluar Cina benteng yang juga sebagai panjak gambang berada didalamnya dan menganggumi musik ini adalah bentuk pengakuan ekternal. Selain itu diakuinya gambang kromong Betawi dengan corak yang berbeda dari gambang kromong yang dipertunjukan oleh orang Cina Benteng di Tangerang juga merupakan pengakuan dari luar atau yang oleh Jenkins disebut prosel identifikasi eksternal.

Makna gambang kromong yang dalam bagi kehidupan orang Cina Benteng karena berkaitan dengan sejarah leluhur mereka menjadikan gambang kromong masih dimainkan sampai saat ini. Walaupun lagu-lagu klasik berbahasa dan berjudul Cina sudah jarang diperdengarkan, karena penyanyi yang dapat menyanyikan lagu ini hanya tinggal satu orang yakni Encim Masnah. Namun, upaya untuk terus mempertahankan kesenian ini sebagai penghormatan kepada leluhur mereka masih mereka jalankan, seperti digelarnya pertunjukan gambang kromong pada perayaan Imlek, shedjit kelenteng dan vihara, serta upacara pernikahan adat Cina.

Pada saat pemberlakuan Inpres, pengkreasian kembali gambang kromong oleh orang Betawi dijadikan keuntungan orang Cina khsusnya seniman gambang untuk "bersembunyi" dibalik identitas Betawi. Keuntungan ini digunakan agar mereka dapat terus memainkan gambang kromong dan memenuhi kebutuhan-kebutuhan hidup para seniman ini, sehingga gambang kromong dapat bertahan dan orang Cina Benteng dapat terus melakukan penghormatan kepada leluhur mereka sebagai bagian dari keyakinan mereka.

Perbedaan corak yang terdapat pada gambang kromong Betawi dan gambang kromong Cina Benteng digunakan mereka sebagai petunjuk identitas ketika berhadapan dengan masyarakat luar. Panjak-panjak gambang kromong yang berasal dari luar Cina Benteng hidup secara harmonis untuk melestarikan musik gambang kromong.

Pemberlakuan Inpres No. 14 tahun 1967 tidak memberikan pengaruh terhadap gambang kromong seperti halnya pengaruh tersebut berlaku untuk Barongsai. Para seniman gambang kromong Cina Benteng menggelar pertunjukan yang nampak pada tradisi-tradisi yang mereka jalankan. Tradisi ini merupakan ciri khas sebagai dasar untuk membedakan orang Cina Benteng dan ethnic group lainnya. Gambang kromong sebagai seni akan memberikan identitas pada orang Cina Benteng pemilik kesenian yang pada gilirannya akan memperkuat eksistensi orang Cina Benteng.

\section{DAFTAR PUSTAKA}

Adi, R. (2003) “Akulturasi Cina Benteng, Wajah Lain Indonesia”. Jakarta: Kompas. 3 Februari.

Barth, F (ed.). (1988). Kelompok Etnik dan Batasannya. Jakarta: UI Press. 
Danandjaja, J. (1987). "Perayaan Imlek dan Pesta Cap Go Me”, Jali-Jali 1:31-41. . (2002) "Keberadaan Suku Bangsa Cina Betawi Mulai Diingat Kembali", Jurnal Betawi 1:45-55.

Kleden, N. (1996). Lenong Betawi, Studi Perbandingan Diakronik, Yayasan Obor dan Yayasan Asosiasi Tradisi Lisan. Jakarta, 1996.

Koentjaraningrat. (2009). Pengantar Ilmu Antropologi. Rineka Cipta. Jakarta.

Kompas. (2004). “Gambang Kromong dan Tradisi Cina Benteng”, Jakarta, 3 Februari. . (2004). Aspirasi Politik Cina Benteng Militer No, Antidiskriminasi Yes. Jakarta: Kompas. 5 Januari: Hal. 3.

Kwa, D, (2009) “Gambang Kromong dan Wayang Cokek.” Dalam Peranakan Tionghoa Indonesia: Sebuah Perjalanan Budaya. Jakarta: Intisari Mediatama dan Komunitas Lintas Budaya Indonesia.

Shahab, Y. Z. (2003) Identitas dan Otoritas: Rekonstruksi Tradisi Betawi. Depok: Laboratorium Antropologi, FISIP UI.

Suparlan, P. (2004a). Antropologi Perkotaan. Jakarta: Yayasan Pengembangan Ilmu Kepolisian.

(2004b). Antropologi Perkotaan. Jakarta: Yayasan Pengembangan Ilmu Kepolisian.

Suryadinata, L, dkk. (2003). Penduduk Indonesia: Etnis dan agama Dalam Era Perubahan politik. Jakarta: LP3ES.

Ruchiat, R. (2000). Iktisar Kesenian Betawi. Jakarta: Dinas Kebudayaan dan Permuseuman Propinsi DKI Jakarta.

Waluyo, E, H. (2013). “Akulturasi Budaya Cina padaArsitektur Mesjid Kuno di Jawa Tengah", Jurnal Desain Vol 1 No 1.

Witanto, E. P. 2004 “Sinolog dari UI: Tionghoa Tidak Homogen”. Jakarta: Kompas. 5 Januari.

Woodward, K.(Ed). (1999). Identity and Difference: Culture, Media and Identities. London: SAGE Publications Ltd.

Wright, S. dan Shore, C. (ed.) (1997) "Policy: A new field of Anthropology", dalam Cris Shore dan Susan Wright (editor) Anthropology of Policy: Critical Perspectives on Governance and Power. London \& New York: Routledge, hal. 3-39. 